\title{
UN backs transgenic crops for poorer nations
}

\section{Mark Schrope}

Rich countries' doubts about genetically modified (GM) crops are damaging to poor countries that urgently need the crops, claims the United Nations' annual report on the status of humankind.

The benefits of GM crops to developing countries are likely to outweigh their risks if their use is properly controlled, says the United Nations (UN) Human Development Report 2001, due out this week. The UN Development Programme has released such reports annually since 1990, but this year's, Making New Technologies Work for Human Development, is the first to concentrate on the value of science and technology.

It states that genetic modification and other emerging technologies should be more widely applied to alleviate poverty and malnutrition in poor countries.

The report is not a blanket endorsement of transgenic crops, however. Rather, it recommends that developed countries consider their expanded use on a case-by-case basis. And it says that the risks of GM crops would be best managed if there was more interaction between rich and poor nations, and also if developing countries with experience of GM crops - particularly China - were to share their information more widely.

Omar Noman, deputy director of the office responsible for the report, says the debate on GM crops has been distorted by "scare stories" from environmentalists. The report says the debate has largely ignored their potential to transform the agriculture of poor countries. But it also notes that the corporations selling the crops have downplayed the difficulties these countries may face in properly monitoring how they are used.

The report highlights the need for rapid development of transgenic crops such as drought- and virus-resistant varieties of the sub-Saharan staple crops sorghum and cassava. But it recommends the mandatory labelling of GM foods so that consumers and nations can make informed decisions. This has been steadfastly opposed by the corporations that own the technology.

The UN's decision to focus this year's report on technology reflects a growing consensus among experts that economic and human development are underpinned not only by basic needs such as adequate health care and clean water, but also by access to science and technology.

Elsewhere the report recommends eliminating costly government monopolies in telecommunications as well as increasing resources for non-primary education. It also backs the development of "appropriate technologies" such as low-literacy touch-screen computers and low-maintenance fuel cells. And it advocates more efforts to develop vaccines for malaria and AIDS and for less-publicized scourges such as river blindness.

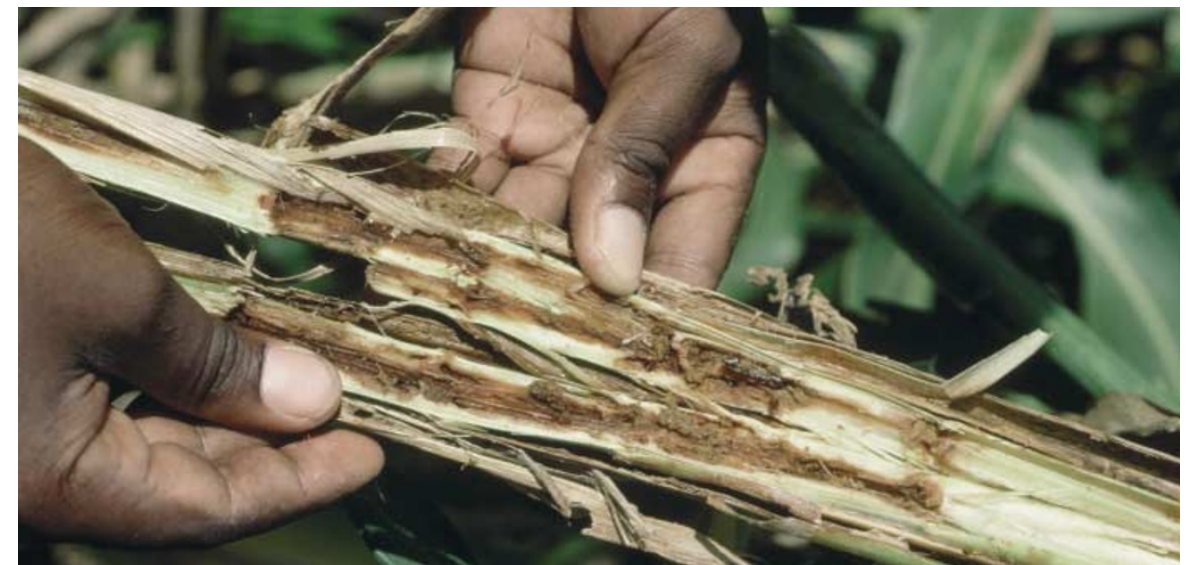

Lending a hand: could biotech prevent damage to sorghum caused by the pest Eldana saccharina?

\section{Arctic university gives collaboration pole position}

\section{Alison Abbott}

A no-walls university in the Arctic region sounds like a pretty chilly prospect. But the newly created University of the Arctic plans to warm up interest in topics of common concern across the region.

The project, which was officially

launched last month, is a network of 20 universities and other academic institutions from 10 countries surrounding the North Pole, including Russia, the United States, Canada and the Scandinavian countries.

The fledgling university will offer a degree in circumpolar studies, a multidisciplinary course that

(1)

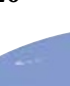

bri

covers both natural and social sciences. And it offers several exchange programmes, such as North2north, which is based in Finland, and funds the exchange of students and staff between institutions.

It also includes a research network called the Northern Research Forum (NRF), which brings together young researchers with other academics, policy-makers and resource managers to exchange information and define research issues that need to be addressed.

Jón Haukur Ingimundarson, an anthropologist from the Stefansson Arctic Institute in Akureyri, Iceland, who helps to run the NRF, says that arctic researchers have many specific problems in common, such as the arctic environment. But researchers in different arctic countries diverge widely in the resources that they have available.

"Icelanders have money, good infrastructure and zero unemployment, for example," he says, "but they need more people. Russians have many highly educated people who remain unemployed and a very poor infrastructure."

The NRF will try to increase cooperation between funding sources and researchers, Ingimundarson adds.

Cynthia Dickson of the Arctic Athabascan Council, which represents around 30,000 people in Arctic North America, says that being part of the University of the Arctic is a lifeline for the population.

"This university allows us to take part in issues of globalization that affect us directly, like climate change and organic pollution," Dickson says.

http://www.urova.fi/home/uarctic 